\title{
Animal Life Cycle Media Using Digital Comics for Fourth- Grade Elementary School Students
}

\section{Kadek Jodi Yuswantara ${ }^{*}$, I Made Citra Wibawa ${ }^{2}$}

1,2 Program Studi Pendidikan Guru Sekolah Dasar, Universitas Pendidikan Ganesha Singaraja, Indonesia

\section{ART ICLE INFO}

Article history:

Received May 12, 2021

Revised May15, 2021

Accepted July 11, 2021

Available online August 25, 2021

\section{Kata Kunci:}

Komik Digital, Siklus Hidup

Hewan, Media Pembelajaran

Keywords:

Digital Comic, Animal Life Cycle, Learning Media

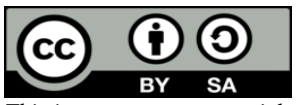

This is an open access article under the CC BY-SA license.

Copyright (C) 2021 by Author.

Published by Universitas Pendidikan Ganesha.

\begin{abstract}
A B S T R A K
Situasi pandemi Covid-19 berdampak pada berbagai aspek kehidupan manusia, salah satunya pendidikan. Pandemi Covid-19 menyebabkan terjadinya perubahan proses penyelenggaraan pembelajaran yang awalnya bertatap muka menjadi pembelajaran daring. Perubahan ini membuat ketersediaan media pembelajaran untuk siswa sekolah dasar dalam mengikuti pembelajaran daring menjadi terbatas. Tujuan dari penelitian ini adalah mengembangkan media siklus hidup hewan menggunakan komik digital untuk siswa kelas IV Sekolah Dasar. Penelitian ini merupakan penelitian pengembangan media menggunakan model ADDIE. Situasi pandemi menyebabkan penelitian hanya dilaksanakan sampai tahap pengembangan. Subjek penelitian ini adalah dua ahli materi, dua ahli media, dan dua praktisi. Objek penelitian ini adalah validitas media siklus hidup hewan menggunakan komik digital. Teknik analisis yang digunakan adalah analisis kualitatif dan kuantitatif. Instrumen pengumpulan data penelitian ini adalah angket rating scale. Data yang diperoleh dari uji validitas media dianalisis untuk mencari persentase skor. Hasil uji media yang diperoleh yaitu uji ahli materi dengan persentase 97,33\%, uji ahli media dengan persentase 98\% dan uji praktisi dengan persentase $91 \%$. Ketiga hasil uji mendapat predikat sangat baik. Dapat disimpulkan bahwa media siklus hidup hewan menggunakan komik digital ini valid dan layak digunakan sebagai media pembelajaran di sekolah. Oleh sebab itu, media media siklus hidup hewan menggunakan komik digital ini dapat dijadikan salah satu alternatif media pembelajaran daring bagi siswa sekolah dasar.
\end{abstract}

\section{A B S T R A C T}

The Covid-19 pandemic situation has an impact on various aspects of human life, one of which is education. The Covid-19 pandemic has caused a change in the process of organizing learning from face-to-face to online learning. This change makes the availability of learning media for elementary school students in participating in online learning to be limited. This study aims to develop an animal life cycle media using digital comics for fourth grade elementary school students. This research is a media development research using the ADDIE model. The pandemic situation causes research to only be carried out until the development stage. The subjects of this research are two material experts, two media experts and two practitioners, while the object of this research is the validity of animal life cycle media using digital comics. The analysis technique used is qualitative and quantitative analysis. The instrument for collecting data in this study was a rating scale questionnaire. The data obtained from the media validity test were analyzed to find the percentage score. The results of the media test obtained were the material expert test with a percentage of $97.33 \%$, the media expert test with a percentage of $98 \%$ and the practitioner test with a percentage of $91 \%$. The three test results received a very good predicate. It can be concluded that the animal life cycle media using digital comics is valid and feasible to be used as a learning medium in schools. Therefore, the animal life cycle media using digital comics can be used as an alternative online learning media for elementary school students.

\section{INTRODUCTION}

Pandemic covid-19 impacted various sectors, including the education sector (Chaturvedi et al., 2021; Dhanalakshmi et al., 2021). The covid-19 pandemic has changed from face-to-face learning to distance learning due to schools being closed to avoid transmission of the corona virus (Liu et al., 2021; Pradas et al., 2021). The application of distance learning during the pandemic has various problems due to emergency conditions without proper preparation and supporting facilities. Teachers must innovate to develop distance learning (Hanik, 2020; Rigianti, 2020). One of the obstacles in distance learning is the availability of learning media. Learning media is very important to use in learning, especially for elementary school students. Based on Piaget's cognitive development stage, elementary school students aged 7-12 are at a concrete operational stage (Byrnes, 2016; Halford, 2016). The concrete operational stage is the stage where students cannot think abstractly, so that what students receive must be concrete so that it is easy to understand (Kazi et al., 2019; Sudbery \& Whittaker, 2018). Learning media that functions to change abstract things for children to become more concrete. 
The learning media available in schools are designed for classroom learning. Ironically, the media available in schools is limited and less diverse (Faizah et al., 2020; Karina et al., 2019). It was exacerbated by the pandemic condition that caused the existing media to be ineffective for distance learning. As in the results of a survey conducted by distributing questionnaires with google forms to fourth-grade teachers of SD Gugus IX, Buleleng sub-district, it was obtained that the media in schools was limited. Learning media in schools during the pandemic are ineffective for distance learning. The use of media in science learning is very important, considering that not all events in science learning occur simultaneously. Media can overcome the limitations of space and time (Basori \& Cobena, 2019; Karo-Karo \& Rohani, 2018). In addition to delivering material, learning media in science learning must be made attractive to attract students' attention to learning. Interesting media will affect student interest in learning and learning outcomes (Siswanah, 2017; Suparman et al., 2020). Based on this, animal life cycle learning media using digital comics were developed for fourth-grade elementary school students. Digital comic media is a sequence of sequential images and presented digitally to convey information (Ratnasari \& Ginanjar, 2020). As for the characteristics of comics, there are characters in the form of images that change poses, and there are speech balloons and backgrounds that match the comic story. In digital comics, various kinds of innovations can be added according to the creator's creativity without eliminating the characteristics of the comic (Aggleton, 2019). Digital comic media is different from conventional comic media because digital comic media is presented with electronic devices to be accessed by students anywhere and anytime.

Research on digital comics has been done before. Research on electronic comics in marine conservation learning for elementary schools results in students being more interested in learning to use comics than student books (Syarah et al., 2019). Digital comic media development research on the ecosystems topic in elementary schools (Mustikasari et al., 2020). Development of educational comics with the theme of clean and healthy life for grade 2 elementary school students with validation of $97.12 \%$ by education experts, $99.04 \%$ by educators, and $96.67 \%$ by students with very valid categories (Harmawati et al., 2020). Development of digital comics for environmental preservation based on religious character values for thematic learning in elementary school students with an average test of 84.83\% with the very good category (Rohmanurmeta \& Dewi, 2019). The development of digital comic learning media to improve student learning achievement in elementary schools results from the validity of the material expert of $84 \%$ with the very high category and the validity of the media expert of $77 \%$ with the high category (Kurniawati \& Koeswanti, 2021). Development of comics for motion teaching materials with the percentage of validity of material experts $76.89 \%$ with a decent category and media experts with $89.17 \%$ with a very good category (Azizul et al., 2020). The development of digital-based comic media towards students' critical thinking skills on metamorphosis material in high class is very well qualified from the validity test of material experts and practitioners (Andayani et al., 2020). The development of digital comics as an educational medium for natural disaster management has received qualifications from both material experts and practitioners (Ratnasari \& Ginanjar, 2020). The development of digital comic media in the fifth-grade social studies subject shows decent results based on the validation results of material experts, material experts, and trials by teachers and student responses. (Sukmanasa et al., 2017). As well as the development of appropriate accounting comic media based on the evaluation of material experts obtaining a score of 79\%, linguists $100 \%$, practitioners $84.64 \%$, and limited trial $82.71 \%$ (Hidayah et al., 2017). Based on this research, it can be concluded that digital comic media is a medium that is suitable for use in learning based on the results that get an average of good and very good criteria.

In previously developed research, there is no digital comic media development research that addresses animal life cycles. In addition, the digital comic media that were developed previously were only digital comic media in general, which were published in the form of image files or books that were published digitally. In developing this media, the product produced is in the form of a video. With publishing in a video format, it can be created by adding dubbing and moving backgrounds. By adding a few things about digital comic media without changing the characteristics of comics, the material delivery can be presented more attractively. Interesting learning media will increase student interest in learning. This study aims to develop animal life cycle learning media using digital comic media tested for its validity to be suitable for use as a learning medium in elementary schools. The development of this medium is expected to be one of the effective learning media.

\section{METHOD}

This research is development research using the ADDIE model. ADDIE consisting of Analysis, Design, Development, Implementation, and Evaluation, is a strategic and systematic model most often used in development (Hess \& Greer, 2016; Rueda et al., 2020; Widyastuti \& Susiana, 2019). This research 
was carried out until the development stage. The implementation and evaluation stages were not carried out due to the Covid-19 pandemic situation. At the analysis stage, several analyzes were carried out; 1) needs analysis by distributing a preliminary study questionnaire in SD cluster IX, Buleleng District, and curriculum analysis to determine the material being developed. 2) analyzing the characteristics of fourthgrade elementary school students to determine student learning characteristics, 3) analyzing instructional media to determine the appropriate media for student needs, and 4) analyzing the curriculum to determine the material developed in the study. Product design is carried out at the planning stage, starting from 1) creating a digital comic storyline, 2) drawing the characters manually, 3) redrawing the characters digitally and drawing the background, 4) coloring characters and backgrounds. At the development stage, the media development stage starts combining characters and backgrounds, giving animation and transitions to the media, adding dubbing and back sound. After the media was developed, the media validity was tested. The media validity test was carried out by providing the media to be assessed by two lecturers as material experts, two lecturers as media experts, and two teachers as practitioners.

The subjects of this study were two lecturers as material experts, two lecturers as media experts, and two teachers as practitioners who tested this comic media. The object of this research is the validity of the media being developed. There are two types of data in this study: quantitative data in the form of a score of the validity of the developed media and qualitative data in criticism, suggestions, and comments from experts used to improve the media being developed. The data collection method used is the rating scale questionnaire method by providing a media assessment instrument that includes seven aspects: material aspects, language, presentation, sound and text, visuals, characterization, and overall appearance to material experts, media experts, and practitioners to assess the media that was developed. The grid for this media assessment instrument is shown in the following table.

Table 1. Assessment Instruments for Material Experts

\begin{tabular}{|c|c|c|c|c|}
\hline No. & Aspect & Dimensions & Number & Total \\
\hline \multirow{3}{*}{1} & \multirow{3}{*}{$\begin{array}{l}\text { Material / } \\
\text { content }\end{array}$} & Completeness and clarity in conveying identity & 1,2 & 2 \\
\hline & & The delivery of clear learning objectives & 3 & 1 \\
\hline & & Deliver material clearly & $4,5,6,7,8$ & 5 \\
\hline \multirow[b]{2}{*}{2} & \multirow{2}{*}{$\begin{array}{l}\text { Language / } \\
\text { Communication }\end{array}$} & The suitability of using language rules & $9,10,11$ & 3 \\
\hline & & $\begin{array}{l}\text { Use language that is easy for students to } \\
\text { understand }\end{array}$ & 12 & 1 \\
\hline \multirow{2}{*}{3} & \multirow[t]{2}{*}{ Presentation } & Go to sequence in the presentation & 13,14 & 2 \\
\hline & & Coherence in the presentation & 15 & 1 \\
\hline Tota & & & & 15 \\
\hline
\end{tabular}

Table 2. Assessment Instruments for Media Experts

\begin{tabular}{|c|c|c|c|c|}
\hline No. & Aspect & Dimensions & Number & Total \\
\hline \multirow{2}{*}{1} & Voice and text & Text is presented clearly & 1,2 & 2 \\
\hline & & Sound is presented clearly & 3,4 & 2 \\
\hline \multirow{3}{*}{2} & Visual & Illustrations are presented clearly & 5,6 & 2 \\
\hline & & Interesting background display & 7,8 & 2 \\
\hline & & The combination in the use of colors & 9,10 & 2 \\
\hline \multirow{2}{*}{3} & Characterization & Character selection & 11,12 & 2 \\
\hline & & Character attractiveness & 14 & 1 \\
\hline 4 & $\begin{array}{l}\text { Overall } \\
\text { Appearance }\end{array}$ & The integration of the overall display & 14,15 & 2 \\
\hline \multicolumn{2}{|c|}{ Total } & & & 15 \\
\hline
\end{tabular}

Table 3. Assessment Instruments for Practitioners

\begin{tabular}{lllll}
\hline No. & Aspect & Dimensions & Number & Total \\
\hline \multirow{4}{*}{1} & Material / content & $\begin{array}{l}\text { Completeness and clarity in conveying } \\
\text { identity } \\
\text { The delivery of clear learning objectives }\end{array}$ & 1,2 & 2 \\
& & $\begin{array}{l}\text { Deliver material clearly } \\
\text { The suitability of using language rules }\end{array}$ & $4,5,6,7,8$, & 5 \\
2 & $\begin{array}{l}\text { Language / } \\
\text { Communication }\end{array}$ & $\begin{array}{l}\text { Using language that is easy for students to } \\
\text { understand }\end{array}$ & 12 & 3 \\
\hline
\end{tabular}




\begin{tabular}{lllll}
\hline No. & Aspect & Dimensions & Number & Total \\
\hline \multirow{2}{*}{3} & Presentation & to the sequence in the presentation & 13,14 & 2 \\
& & Integrity in presentation & 15 & 1 \\
4 & Voice and text & Text is presented clearly & 16,17 & 2 \\
& & Sound is presented clearly & 18,19 & 2 \\
\multirow{2}{*}{5} & \multirow{2}{*}{ Visual } & Illustrations are presented clearly & 20,21 & 2 \\
& & Interesting background display & 22,23 & 2 \\
\multirow{2}{*}{6} & \multirow{2}{*}{ Characterization } & The combination in the use of colors & 24,25 & 2 \\
& & Character selection & 26,27 & 2 \\
7 & Overall & Character attractiveness & 28 & 1 \\
7 & Appearance & Overall appearance integration & 29,30 & 2 \\
\hline Total & & & $\mathbf{3 0}$ \\
\hline
\end{tabular}

Before carrying out the media validity test, the assessment instrument must be valid so that it is suitable to be used to assess the media. An instrumented test was performed using cross-tabulation of the Gregory index to determine the feasibility of the instrument. Based on the instrument validity test results, it was found that the assessment instrument for material experts was 0.93 . The assessment instrument for media experts was 0.97 , and the media assessment instrument for practitioners is 0.95 . The three results of the instrument validity test are in the very high category of instrument validity.

The data analysis method used in this research is quantitative descriptive analysis method and qualitative descriptive analysis method. Qualitative analysis in this study was carried out by analyzing comments, criticisms, and suggestions from experts used to improve the media. The quantitative analysis in this study was carried out after the media validity test score was obtained by finding the average percentage score of material experts, the average percentage score of media experts, and practitioners' average percentage score. The percentage obtained is then converted according to the benchmark reference score achievement of the media validity score on a scale of five to obtain meaning and decision making. This media development is said to be successful if the percentage of the media validity score is at least well qualified with a minimum percentage of $75 \%$. If it meets the minimum criteria, the media developed can be suitable for learning media in elementary schools

\section{RESULT AND DISCUSSION}

\section{Result}

The analysis stage was carried out by analyzing Needs analysis, based on distributing questionnaires using google forms to fourth-grade teachers of SD Gugus IX, Kecamatan Buleleng subdistrict on November 10-12, 2020. Data on media availability in limited schools was obtained following the questionnaire results distributed that $100 \%$ of teachers stated that the media in schools was limited. Instructional media in schools during the pandemic period were ineffective following the results of a distributed questionnaire that stated that $100 \%$ of teachers declared ineffective. The teacher lacks media for distance learning. According to the questionnaire distribution, $100 \%$ of teachers stated a lack of media in distance learning. Less diverse science learning media with $56 \%$ of teachers using PowerPoint, pictures, and videos, $33 \%$ using IPA KIT, and $11 \%$ not using media. Digital comic media has never been used in learning, with $100 \%$ of teachers who have never used it. 2) Analysis of student characteristics is carried out by finding information about fourth-grade elementary school students' development by conducting literature studies in various sources. It is found that elementary school students are at the concrete operational stage to use concrete things to understand them easily. 3) Media analysis is carried out by looking for innovative media information for more interesting learning. It was found that digital comic media is an interesting medium because students being able to listen to the material presented with digital comics can enjoy the storyline and watch the images displayed. 4) Curriculum analysis is carried out to find material that has never been developed and is important. The material on the life cycle is still a little developed and has never been developed in digital comics based on curriculum analysis, teacher books, and student books in the form of analysis of core competencies, basic competencies, learning objectives, and learning objectives,

At the design stage, media design is carried out, preceded by designing a digital comic storyline in the form of a conversation table, a picture of the characters during the conversation, and the displayed background. After the digital comic storyline is finished, character design is done by drawing comic sketches, as shown in Figure 1. Then proceed with electronic redrawing in the Corel Draw x8 using the 
image tracing technique 2.After the character is complete and perfected, the character coloring process is carried out as in Figure 3.
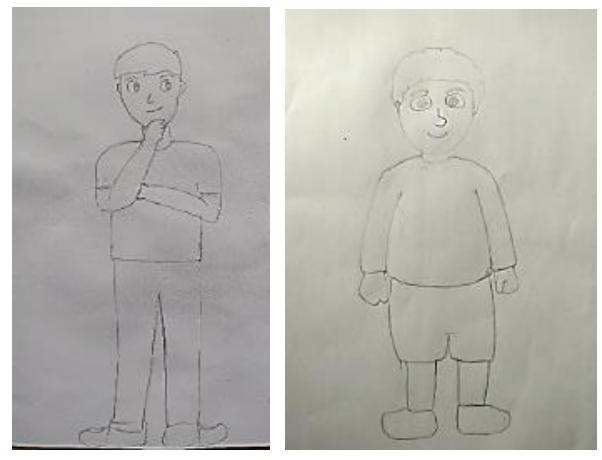

Figure 1. Drawing a comic sketch

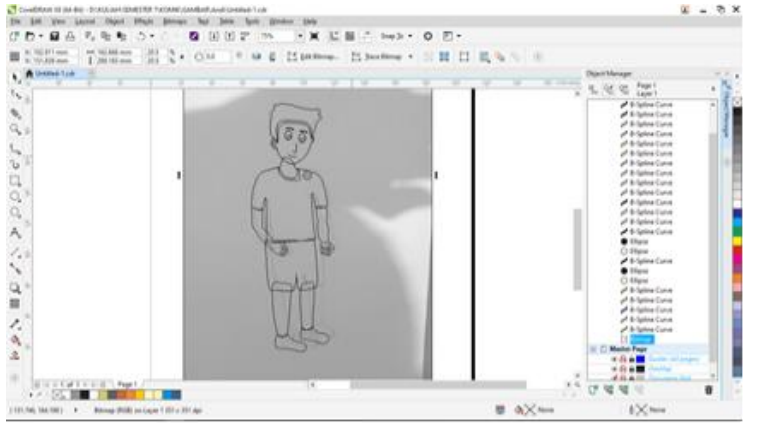

Figure 2. Tracing Process

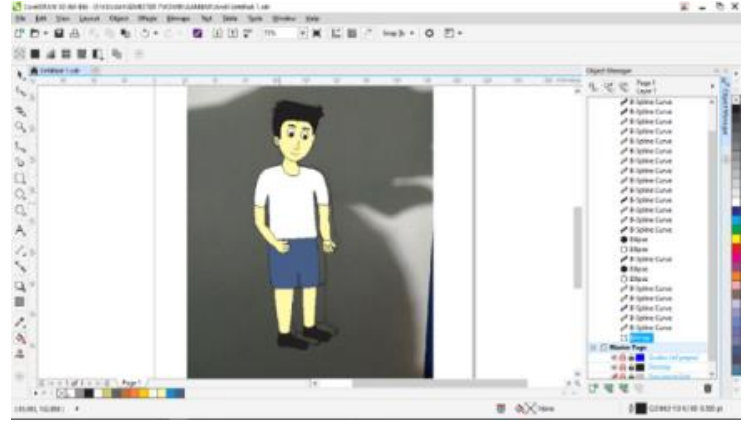

Figure 3. Character coloring process

At the development stage, characters, backgrounds, and images are combined using the 2019 PowerPoint. During this merger, word balloons and conversation text were also carried out, and animation was given as in Figure 4. Then the PowerPoint export results in the form of edited videos using the Filmora 10. In this video editing stage, dubbing and back sound are added, and video transitions are added. The video editing process is as shown in Figure 5.

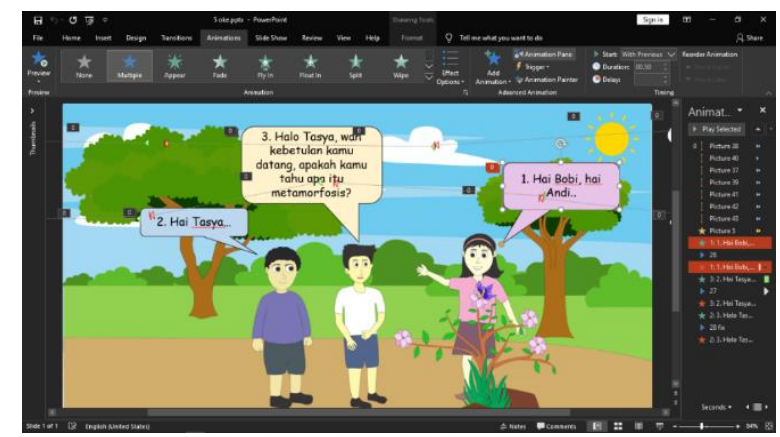

Figure 4. The merging process

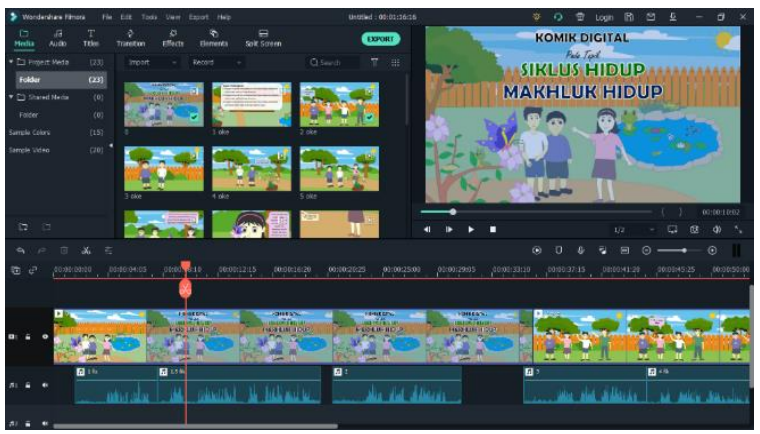

Figure 5. Video editing process

This digital comic consists of a cover, instructions for use, purpose, introduction, material, and conclusion. The cover is the outer part of this research that describes what will be conveyed in this comic. The cover can be seen in Figure 6. Part of the material from this comic is contained in conversation balloons between characters. In addition to the text material, part of the material is also clarified with pictures in Figure 7. 


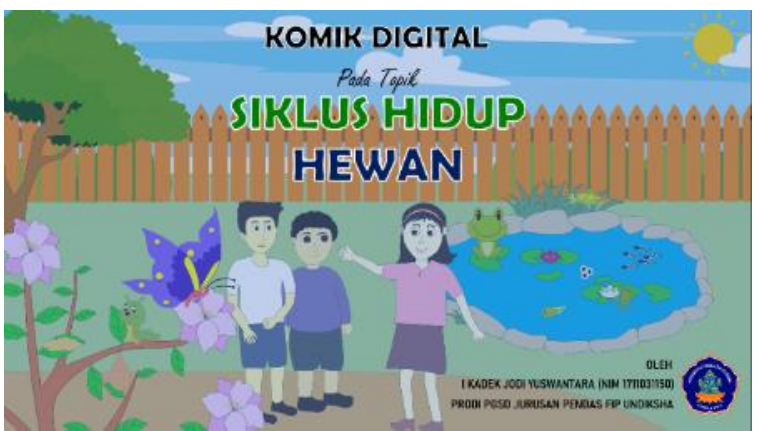

Figure 6. Cover of digital comics

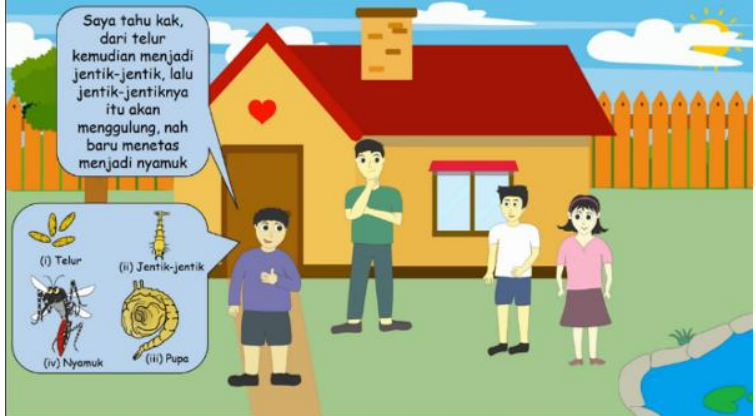

Figure 7. Content of digital comics

After the media was developed, the media validity was tested using the media assessment instrument. The results obtained from the media test were analyzed by looking for the average percentage score of each expert. The results obtained from this study are as shown in Table 4.

Table 4. Percentage of Average Media Validity

\begin{tabular}{llll}
\hline No & Trial Subject & Persentase rata-rata Skor & Criteria \\
\hline 1 & Media Expert & $97.33 \%$ & Very good \\
2 & Material Expert & $98 \%$ & Very good \\
3 & Practitioner & $91 \%$ & Very good \\
\hline
\end{tabular}

The average percentage of media validity by material experts is $97.33 \%$, so that the media validity qualification obtained by material experts is very good. The average percentage of media validity by media experts is $98 \%$. The qualification of the average media validity score obtained is very good. For the practitioner's assessment of 91\%, practitioners' average percentage of media validity also received a very good predicate. It means that this media is very good to be applied as a learning medium in elementary schools. As for the comments from material experts, media experts, and practitioners, 1) the duration of the video is further slowed down to suit the students' abilities. 2) At the end of the comic, greetings and greetings are added to those who help the media-making process, and 3) pay more attention to the grammar of writing so that it fits the characteristics of elementary students

\section{Discussion}

The results obtained in the media validity test qualify very well. It is inseparable from the aspects assessed by this media, which also received very good ratings. The aspects of this media ass essment are material/content aspects, linguistic aspects, presentation aspects, sound and text aspects, visual aspects, characterization aspects, and overall appearance aspects. The material aspect of this digital comic is very well qualified. It indicates that the completeness of identity in this comic is good. The media identity completeness is very important because the basic information from the media is contained in its identity. In this media, the objectives and material are conveyed clearly and following fourth-grade elementary school students' characteristics. The ability of students to understand the material varies according to the stage of children's cognitive development (Antara et al., 2020; Byrnes, 2016; Halford, 2016). Based on this, this media delivers material following the stage of child development so that the assessment of the material aspects gets a very good assessment.

The linguistic aspect is very well qualified. It means that the use of language is following the characteristics of elementary school students. The language in this media uses good, simple, and easy language for children to understand. The use of good and simple language is important to use in media because elementary school children have different stages of language development from adults (Firmansyah, 2018; Khaulani et al., 2020). In the presentation aspect, it gets very good qualifications. It indicates that the ordered and comic presentations integrate the material and the story being told. The integration with the stories that are told makes children interested in listening to this media. In addition to learning, children can enjoy the storyline presented. The combination of material with stories allows children to learn and listen to stories that add to the appeal of this media because learning from listening to stories is effectively used and interesting for children (Astuti et al., 2020; Surachman, 2020). The sound and text aspects of this digital comic media are highly qualified. In the selection of text, sound and music are following fourth-grade elementary school students' characteristics. Besides being able to read conversations in comics, children can also listen to character conversations. There is also back sound music that matches the characteristics of the story. The back sound music in the learning carried out 
affects learning outcomes (Hermita \& Zufriady, 2019; Ramadhona, 2016). It assesses the voice and text aspects very well qualified.

The visual and characterization aspects are very well qualified. The visuals displayed are the suitability of illustrations with the subject matter, the accuracy of the illustrations, the background, the use of color and color harmony, and the selection of characters according to the characteristics of fourthgrade elementary school students. The use of colors in the developed media is adapted to the characteristics of elementary school students by using bright colors, interesting characters to increase students' imagination. Media needs to be developed to be interesting, full of colors and images to increase students' imagination (Suparman et al., 2020). The overall performance aspect is very well qualified. The proportions of the placement of illustrations, characters, background, and word balloons are appropriate and interesting according to fourth-grade elementary school students' characteristics. Good media performance makes students more interested in learning. It is based on research (Mustikasari et al., 2020; Syarah et al., 2019), showing that electronic comics make students more interested in learning than student books.

The results of the assessment are very good on these aspects of media assessment. (Hidayah et al., 2017) The evaluation of material experts gets a score of $79 \%$, linguists $100 \%$, practitioners $84.64 \%$, and limited trials of $82.71 \%$ based on the constituent aspects that get a very good category in each expert. Other studies are not much different. (Andayani et al., 2020; Azizul et al., 2020; Harmawati et al., 2020; Kurniawati \& Koeswanti, 2021; Ratnasari \& Ginanjar, 2020; Sukmanasa et al., 2017) It also showed that the development of digital comics gets good to very good qualifications with high scores. The results obtained are related to the characteristics of the comic itself, which is the arrangement of ordered pictures and storytelling, which is an interesting thing for elementary school students. It shows that the use of digital comics has a positive impact on learning. Likewise, the development of this media has received a very good qualification assessment based on media testing by two material experts. Two media experts and two practitioners can be a suitable medium to be applied in elementary schools.

\section{CONCLUSION}

The development of animal life cycle media using digital comics is valid and suitable for learning in elementary schools. As for the suggestion for further research, the development of digital comic media continued until the evaluation stage to obtain more accurate results and follow the characteristics of students.

\section{REFERENCES}

Aggleton, J. (2019). Defining Digital Comics: A British Library Perspective. Journal of Graphic Novels and Comics, 10(4), 393-409. https://doi.org/10.1080/21504857.2018.1503189.

Andayani, F., Maula, L. H., \& Sutisnawati, A. (2020). Pengembangan Media Komik Berbasis Digital terhadap Kemampuan Berpikir Kritis Siswa pada Materi Metamorfosis di Kelas Tinggi. Diknas Matappa: Jurnal Ilmu Pendidikan Dasar, 3(2). https://doi.org/10.31100/dikdas.v3i2.666.

Antara, I. G. W. S., Sudarma, I. K., \& Dibia, I. K. (2020). The Assessment Instrument of Mathematics Learning Outcomes Based on HOTS toward Two-Dimensional Geometry Topic. Indonesian Journal Of Educational Research and Review, 3(2), 19-24. https://doi.org/ijerr.v3i2.25869.g15588.

Astuti, N. B., Sari, E. P., \& Felle, G. M. (2020). Buku Cerita dan Buku Saku sebagai Media Edukasi Gizi untuk Meningkatkan Pengetahuan Sayur dan Buah. Gema Kesehatan, 11(1). https://doi.org/10.47539/gk.v11i1.86.

Azizul, A., Riski, W. Y., Fitriyani, D. I., \& Sari, I. N. (2020). Pengembangan Bahan Ajar Komik Digital pada Mater Gerak. Vox Edokasi: Jurnal Ilmiah Ilmu Pendidikan, 11(2). https://doi.org/10.31932/ve.v11i2.829.

Basori, B., \& Cobena, D. Y. (2019). Pengembangan Media Berbasis Mind Map untuk Meningkatkan Pemahaman Siswa pada Pelajaran Teknik Pengolahan Video. Elinvo (Electronics, Informatics, and Vocational Education), 4(2). https://doi.org/10.21831/elinvo.v4i2.18434.

Byrnes, J. P. (2016). Piaget's Cognitive-Developmental Theory. In The Curated Reference Collection in Neuroscience and Biobehavioral Psychology (pp. 543-552). Elsevier Science Ltd. https://doi.org/10.1016/B978-0-12-809324-5.23519-0.

Chaturvedi, K., Vishwakarma, D. K., \& Singh, N. (2021). Covid-19 and Its Impact on Education, Social Life and Mental Health of Students: A Survey. Children and Youth Services Review, 121. https://doi.org/10.1016/j.childyouth.2020.105866.

Dhanalakshmi, R., Anuja Mary, A., Shrijith, D., \& Vijayaraghavan, N. (2021). A Study on Covid-19 - 

Impacting
Indian
Education.
Materials
Today:
Proceedings.

https://doi.org/10.1016/j.matpr.2021.02.786.

Faizah, N. okta, Sudatha, I. G. W., \& Simamora, A. H. (2020). Pengembangan Multimedia Pembelajaran IPA untuk Meningkatkan Hasil Belajar. Journal of Education Technology, 4(1). https://doi.org/10.23887/jet.v4i1.24091.

Firmansyah, D. (2018). Analysis of Language Skills in Primary School Children (Study Development of Child Psychology of Language). PrimaryEdu - Journal of Primary Education, 2(1). https://doi.org/10.22460/pej.v1i1.668.

Halford, G. S. (2016). Cognitive Developmental Theories. In The Curated Reference Collection in Neuroscience and Biobehavioral Psychology (pp. 298-308). Elsevier Science Ltd. https://doi.org/10.1016/B978-0-12-809324-5.05787-4.

Hanik, E. U. (2020). Self Directed Learning Berbasis Literasi Digital pada Masa Pandemi Covid-19 di Madrasah Ibtidaiyah. Elementary: Islamic Teacher Journal, 8(1). https://doi.org/10.21043/elementary.v8i1.7417.

Harmawati, D., Hasanah, N., Belwawin, S. M., \& Hidayat, S. H. (2020). Developing of an Educative Comic on the Theme of Clean and Healthy Life for Grade 2 Students of the Elementary Schools of YPPK Biankuk Merauke. Enfermeria Clinica, 30, 371-373. https://doi.org/10.1016/j.enfcli.2019.07.120.

Hermita, N., \& Zufriady, Z. (2019). Pengaruh Model Pembelajaran Quantum Learning Bernuansa Musik Klasik terhadap Hasil Belajar IPA Kelas VII di SDN 58 dan SDN 82 Pekanbaru. Jurnal Pajar (Pendidikan Dan Pengajaran), 3(4). https://doi.org/10.33578/pjr.v3i4.7414.

Hess, A. K. N., \& Greer, K. (2016). Designing for Engagement: Using the ADDIE Model to Integrate HighImpact Practices into an Online Information Literacy Course. Communications in Information Literacy. https://doi.org/10.15760/comminfolit.2016.10.2.27.

Hidayah, Y. F., Siswandari, S., \& Sudiyanto, S. (2017). Pengembangan Media Komik Digital Akuntansi pada Materi Menyusun Laporan Rekonsiliasi Bank untuk Siswa SMK. Jurnal Pendidikan dan Kebudayaan, 2(2). https://doi.org/10.24832/jpnk.v2i2.588.

Karina, D., Yulita, I., \& Ramdhani, E. P. (2019). Pengembangan Media Pembelajaran Ular Tangga Kimia (Ultakim) Berbasis Kemaritiman pada Materi Hakikat Ilmu Kimia. Jurnal Zarah, 7(1). https://doi.org/10.31629/zarah.v7i1.1286.

Karo-Karo, I. R., \& Rohani, R. (2018). Manfaat Media dalam Pembelajaran. Axiom: Jurnal Pendidikan dan Matematika, 7(1). https://doi.org/10.30821/axiom.v7i1.1778.

Kazi, S., Kazali, E., Makris, N., Spanoudis, G., \& Demetriou, A. (2019). Cognizance in Cognitive Development: A Longitudinal Study. Cognitive Development, 52. https://doi.org/10.1016/j.cogdev.2019.100805.

Khaulani, F., S, N., \& Irdamurni, I. (2020). Fase dan Tugas Perkembangan Anak Sekolah Dasar. Jurnal Ilmiah Pendidikan Dasar, 7(1). https://doi.org/10.30659/pendas.7.1.51-59.

Kurniawati, U., \& Koeswanti, H. D. (2021). Pengembangan Media Pembelajaran Kodig untuk Meningkatkan Prestasi Belajar Siswa di Sekolah Dasar. Jurnal Basicedu, 5(2). https://doi.org/10.31004/basicedu.v5i2.843.

Liu, Q., Zhou, Y., Xie, X., Xue, Q., Zhu, K., Wan, Z., Wu, H., Zhang, J., \& Song, R. (2021). The Prevalence of Behavioral Problems among School-Aged Children in Home Quarantine During the COVID-19 Pandemic in China. Journal of Affective Disorders, 279, 412-416. https://doi.org/10.1016/j.jad.2020.10.008.

Mustikasari, L., Priscylio, G., Hartati, T., \& Sopandi, W. (2020). The Development of Digital Comic on Ecosystem for Thematic Learning In Elementary Schools. Journal of Physics: Conference Series, 1469(1). https://doi.org/10.1088/1742-6596/1469/1/012066.

Pradas, S. I., García, Á. H., Peláez, J. C., \& Prieto, J. L. (2021). Emergency Remote Teaching and Students' Academic Performance in Higher Education During the COVID-19 Pandemic: A Case Study. Computers in Human Behavior, 119. https://doi.org/10.1016/j.chb.2021.106713.

Ramadhona, R. (2016). Penggunaan Mind Map Diiringi Musik Klasik dalam Pembelajaran Matematika untuk Siswa Kelas VIII SMPN 1 Sawahlunto. Jurnal Pendidikan Matematika, 10(2). https://doi.org/10.22342/jpm.10.2.3636.87-92.

Ratnasari, D. T., \& Ginanjar, A. (2020). Pengembangan Komik Digital sebagai Media Edukasi Penanggulangan Bencana Alam. Naturalistic: Jurnal Kajian Penelitian Pendidikan dan Pembelajaran, 4(1). https://doi.org/10.35568/naturalistic.v4i1.679.

Rigianti, H. A. (2020). Kendala Pembelajaran Daring Guru Sekolah Dasar di Banjarnegara. Elementary School: Jurnal Pendidikan dan Pembelajaran Ke-SD-an, 7(2). https://doi.org/10.31316/esjurnal.v7i2.768.

Rohmanurmeta, F. M., \& Dewi, C. (2019). Pengembangan Komik Digital Pelestarian Lingkungan Berbasis Nilai Karakter Religi untuk Pembelajaran Tematik pada Siswa Sekolah Dasar. Muaddib : Studi 
Kependidikan dan Keislaman, 1(2). https://doi.org/10.24269/muaddib.v1i2.1213.

Rueda, R. A. S., Rueda, É. P. S., \& Rueda, R. D. S. (2020). Analysis and Design of the Web Game on Descriptive Statistics through the Addie Model, Data Science and Machine Learning. International Journal of Education in Mathematics, Science and Technology, 8(3), 245-260. https://doi.org/10.46328/IJEMST.V8I3.759.

Siswanah, E. (2017). Penggunaan Media Animasi dalam Pembelajaran Trigonometri untuk Meningkatkan Hasil Belajar Mahasiswa Tadris Matematika Iain Walisongo Semarang. Phenomenon: Jurnal Pendidikan MIPA, 3(2). https://doi.org/10.21580/phen.2013.3.2.117.

Sudbery, J., \& Whittaker, A. (2018). Piaget's Theory of Cognitive Development. Human Growth and Development, 00(0). https://doi.org/10.4324/9780203730386-15.

Sukmanasa, E., Windiyani, T., \& Novita, L. (2017). Pengembangan Media Pembelajaran Komik Digital pada Mata Pelajaran Ilmu Pengetahuan Sosial bagi Siswa Kelas V Sekolah Dasar di Kota Bogor. Jurnal Pendidikan Sekolah Dasar, 3(2), 171. https://doi.org/10.30870/jpsd.v3i2.2138.

Suparman, I. W., Eliyanti, M., \& Hermawati, E. (2020). Pengaruh Penyajian Materi dalam Bentuk Media Komik Terhadap Minat Baca dan Hasil Belajar. Pedagogi: Jurnal Penelitian Pendidikan, 7(1). https://doi.org/10.25134/pedagogi.v7i1.2860.

Surachman, D. (2020). Media Buku Cerita: Efektifitasnya untuk Meningkatkan Hasil Belajar Bahasa Indonesia Siswa Sekolah Dasar. Gema Wiralodra, 11(2). https://doi.org/10.31943/gemawiralodra.v11i2.99.

Syarah, E. S., Yetti, E., Fridani, L., Yufiarti, Hapidin, \& Pupala, B. (2019). Electronic Comics in Elementary School Science Learning for Marine Conservation. Jurnal Pendidikan IPA Indonesia, 8(4), 500-511. https://doi.org/10.15294/jpii.v8i4.19377.

Widyastuti, E., \& Susiana. (2019). Using the ADDIE Model to Develop Learning Material for Actuarial Mathematics. Journal of Physics: Conference Series. https://doi.org/10.1088/1742$6596 / 1188 / 1 / 012052$. 